\title{
Modulatory role of resveratrol on cytotoxic activity of cisplatin, sensitization and modification of cisplatin resistance in colorectal cancer cells
}

\author{
ABDEL-MONEIM M. OSMAN ${ }^{1,2}$, HAMDAN S. AL-MALKI ${ }^{1}$, SAMEER E. AL-HARTHI ${ }^{1}$, \\ AMR A. EL-HANAFY ${ }^{3,4}$, HASSAN M. ELASHMAOUI ${ }^{3,5}$ and MOHAMED F. ELSHAL ${ }^{6,7}$ \\ ${ }^{1}$ Pharmacology Department, Faculty of Medicine, King Abdulaziz University, Jeddah 21589, Saudi Arabia; \\ ${ }^{2}$ National Cancer Institute, Cairo University, Cairo, Egypt; ${ }^{3}$ Department of Biological Science, Faculty of Science, \\ King Abdulaziz University, Jeddah 21589, Saudi Arabia; ${ }^{4}$ City of Scientific Research and Technology Application, \\ Borg El-Arab, Alexandria, Egypt; ${ }^{5}$ National Research Center, Giza, Egypt; ${ }^{6}$ Department of Biochemistry, Faculty of Science, \\ King Abdulaziz University, Jeddah 21589, Saudi Arabia; ${ }^{7}$ Department of Genetic Engineering and Biotechnology, \\ Menoufia University, Menoufia, Egypt
}

Received December 24, 2013; Accepted August 29, 2014

DOI: $10.3892 / \mathrm{mmr} .2015 .3513$

\begin{abstract}
Colorectal cancer (CRC) is a leading cause of cancer-associated mortality worldwide. Cisplatin (CIS) is one of the most active cytotoxic agents in current use and it has proven efficacy against various human malignancies. However, its clinical usefulness has been restricted by detrimental side effects, including nephrotoxicity and myelosuppression. The aim of the present study was to attempt to decrease the required dose of CIS, in order to minimize its side effects, and increase its capability to arrest, delay or reverse carcinogenesis. In addition, the present study aimed to ameliorate CIS-resistance in CRC cells, using the natural compound resveratrol (RSVL). RSVL (3,4', 5-trihydroxy-trans-stilbene) is a naturally occurring polyphenol present in the roots of white hellebore (Veratrum grandiflorum $\mathrm{O}$. Loes) and extracted from $>70$ other plant species. RSVL can exert antioxidant and anti-inflammatory activities, and it has been shown to be active in the regulation of numerous cellular events associated with carcinogenesis. The present study evaluated the effects of RSVL on sensitization of both parent and CIS-resistant HCT-116 CRC cells to the action of cisplatin. The CIS was administered at a dose of 5 and $20 \mu \mathrm{g} / \mathrm{ml}$, and CIS cytotoxicity, apoptosis, cell cycle and cisplatin cellular uptake were examined in the presence and absence of RSVL (15 $\mu \mathrm{g} / \mathrm{ml})$. RSVL treatment showed anti-proliferative effects and enhanced the cytotoxic effects of CIS against the growth of both parent and CIS-resistant HCT-116 CRC cells, with a half
\end{abstract}

Correspondence to: Professor Abdel-Moneim Mahmoud Osman, Pharmacology Department, Faculty of Medicine, King Abdulaziz University, 7 Abdullah Sulayman Street, Jeddah 21589, Saudi Arabia E-mail: moneimosman@hotmail.com

Key words: colorectal cancer, cisplatin, resveratrol, interaction maximal inhibitory concentration of $4.20 \mu \mathrm{g} / \mathrm{ml}$ and $4.72 \mu \mathrm{g} / \mathrm{ml}$ respectively. RSVL also induced a significant increase in the early apoptosis fraction and enhanced the subsequent apoptotic effects of CIS. The cellular uptake of CIS was significantly increased in the presence of RSVL, as compared with CIS treatment alone, and RSVL treatment sensitized the CIS-resistant HCT-116 cells. In conclusion, RSVL treatment increased the cytotoxic activity of CIS against the growth of both parent and CIS-resistant HCT-116 CRC cells.

\section{Introduction}

The Kingdom of Saudi Arabia is considered to have a low incidence of colorectal cancer (CRC); however, the incidence of CRC and related mortalities has been steadily increasing over the past 20 years. It currently ranks first among all cancers in males and third among females in Saudi Arabia $(1,2)$. Chemotherapy is often used as the main treatment option in the overall therapy of most cancers. Cisplatin (CIS) is one of the most active cytotoxic agents in current use that has a proven efficacy against numerous human malignancies, either alone or in combination with other cytocidal drugs. However, its clinical usefulness has been restricted by detrimental side effects, including nephrotoxicity $(3,4)$. The development of tumor resistance to chemotherapy presents a major complication in cancer therapy. Chemosensitization is one strategy that may be used to overcome chemoresistance. It is based on the use of one drug to enhance the activity of another, by modulating one or more mechanisms of resistance. In an attempt to minimize the side effects of CIS, and at the same time increase its anticancer efficacy, various approaches have been studied (5-8). One approach is the search for natural compounds with chemopreventative or anticancer properties, that may be used in combination with CIS. A potential natural chemosensitizer is resveratrol (RSVL). RSVL (3,4', 5-trihydroxy-trans-stilbene) was first isolated in 1940 as a component of the roots of white hellebore (Veratrum 
grandiflorum $\mathrm{O}$. Loes), since then it has been identified in extracts from $>70$ different species of plant $(3,9)$. The aim of the present study was to explore whether RSVL may enhance the cytotoxic effects of CIS against the growth of CRC cells. The possible mechanisms of drug interactions between CIS and RSVL were investigated, regarding CIS cytotoxicity, apoptosis induction, cellular uptake and cell cycle distribution of CRC cells in the presence and absence of RSVL.

\section{Materials and methods}

Drugs and chemicals. The CIS "Ebewe" and RSVL were purchased from Sigma-Aldrich (St Louis, MO, USA). The CIS was stored at room temperature (not exceeding $25^{\circ} \mathrm{C}$ ), protected from light and diluted in phosphate-buffered saline (PBS). RSVL was supplied as a white powder, with a yellow cast and stored at $-20^{\circ} \mathrm{C}$. Media and other tissue culture reagents used in the present study were all purchased Sigma-Aldrich. The cell cycle determination kit was purchased from Cayman Chemical Company (Ann Arbor, MI, USA).

Cells and cell cultures. The HCT-116 human CRC cells were acquired from Professor Abdel-Moneim M. Osman, from the National Cancer Institute, Cairo University (Egypt). The cells were grown as monolayer cultures and maintained in RPMI-1640 medium, supplemented with penicillin G and streptomycin antibiotics and $10 \%$ fetal bovine serum (FBS), and were cultured at $37^{\circ} \mathrm{C}$ in a humidified incubator containing $5 \% \mathrm{CO}_{2}$. The cells were collected by trypsinization and passaged every 4-6 days. The passage level was in the range of 5-10, following receipt of the cell line from the source.

Establishment of CIS-resistant HCT-116 colorectal cancer cells. An isogenic model of cisplatin resistance was generated in a panel of parent HCT-116 cells. The resistant cell line was established using dose-dependent cytotoxicity curves where the cells were exposed to stepwise increasing concentrations of CIS. The parental HCT-116 cell line was exposed to a concentration of CIS between 0.05 and $0.50 \mu \mathrm{g} / \mathrm{ml}$, over a period of five months. The exposure to each concentration was continuous for $72 \mathrm{~h}$, the drug-containing media was then removed and replaced with fresh media containing the same concentration of CIS for a further $72 \mathrm{~h}$. Typically, the concentration was increased by $0.05 \mu \mathrm{g} / \mathrm{ml}$ at each step, with four exposures to each concentration, allowing for growth recovery between the cycles. The cells were then exposed to the next concentration, until the final concentration was reached by the same manner. Following the exposure to the final concentration, the half maximal inhibitory concentrations $\left(\mathrm{IC}_{50}\right.$ ) were re-assessed in the CIS-resistant cell line. Once the resistance had been developed, the cell line was maintained by a continuous exposure to $0.5 \mu \mathrm{g} / \mathrm{ml}$ CIS. The cells were grown as a monolayer culture in RPMI-1640, supplemented with antibiotics [penicillin $(100 \mathrm{IU} / \mathrm{ml})$ and streptomycin $(100 \mu \mathrm{g} / \mathrm{ml})]$ and $10 \%$ FBS. The cells were cultured at $37^{\circ} \mathrm{C}$ in a humidified $5 \% \mathrm{CO}_{2}$ atmosphere, collected by trypsinization and passaged every 4-6 days. The doubling time of the CIS-resistant cells was $37 \mathrm{~h}$, as compared with $28 \mathrm{~h}$ in the parent cell line.

Assessment of cytotoxic activity. Cytotoxicity was determined using the sulforhodamine B (SRB) method, as previously described by Skehan et al (10). The cells were seeded in 96 well microtiter plates, at a concentration of $40 \times 10^{3}$ cells/well in RPMI-1640 medium. Following a $24 \mathrm{~h}$ incubation the cells were incubated for an additional $48 \mathrm{~h}$ with various concentrations of CIS $(1.25,2.5-20 \mu \mathrm{g} / \mathrm{ml})$ and RSVL $(15 \mu \mathrm{g} / \mathrm{ml})$ supplied simultaneously (two wells were used for each concentration). The incubation was followed by the addition of $50 \mu \mathrm{l}$ of $50 \%$ cold trichloroacetic acid for $1 \mathrm{~h}$ at $4^{\circ} \mathrm{C}$, and the supernatant was discarded. The plates were washed five times with water and air dried, and then stained for 30 min with $100 \mu 10.4 \%$ (w/v) SRB solution in $1 \%$ acetic acid. The unbound dye was removed by five washes with $1 \%$ acetic acid and the plates were air dried. The bound stain was solubilized using $100 \mu \mathrm{l} /$ well $10 \mathrm{mM}$ Tris base (pH 10.5) for $10 \mathrm{~min}$. The optical density (OD) was measured using an ELx808 absorbance microplate reader (BioTek Instruments Inc., Winooski, VT, USA) at a wavelength of $490-530 \mathrm{~nm}$. The surviving fraction $=$ OD of treated cells $/ O D$ of control cells. The $\mathrm{IC}_{50}$ of CIS (necessary to produce $50 \%$ inhibition of cell growth) was calculated from the following linear equation of the survival fraction curve:

$$
\mathrm{Y}=\mathrm{mX}+\mathrm{b}
$$

$\mathrm{Y}=0.5$ (the surviving fraction when there is a $50 \%$ inhibition of cell growth); $\mathrm{m}=$ the slope; $\mathrm{X}=$ dose of CIS that induces $50 \%$ inhibition; $\mathrm{b}=$ the $\mathrm{y}$-intercept.

Flow-cytometric assay of apoptosis. The percentage of apoptotic cells was quantified by Annexin V-fluorescein isothiocyanate (FITC)-propidium iodide (PI) double staining, using an Annexin V-FITC apoptosis detection kit (Sigma-Aldrich, Saint Louis, MO, USA), according to the method of Kuypers et al (11). The cells were seeded in 6 well plates, at a cell density of 5-8 x $10^{5}$ cells/well, in RPMI-1640 supplemented with $10 \%$ FBS, $1 \%$ penicillin/streptomycin, and $1 \%$ L-glutamine, the plate was then incubated for $24 \mathrm{~h}$. The cells were incubated with CIS ( 5 and $20 \mu \mathrm{g} / \mathrm{ml}$ ), either alone or in combination with $15 \mu \mathrm{g} / \mathrm{ml}$ RSVL for $48 \mathrm{~h}$. Following the incubation, the medium was removed and the cells were washed with PBS. The cells were detached using trypsin/EDTA, washed once with cold PBS and $10^{5}-10^{6}$ cells were resuspended in $100 \mu \mathrm{l}$ Annexin $\mathrm{V}$ incubation reagent. The solution was incubated in the dark for $15 \mathrm{~min}$ at room temperature. A total of $400 \mu \mathrm{l} 1 \mathrm{X}$ binding buffer was added to each $100 \mu \mathrm{l}$ sample and measured using a Navios flow cytometer (Beckman Coulter, Brea, CA, USA) within one hour, in order to obtain the maximal signal.

Cell cycle analysis. The cells were seeded in 6 well plates at a density of $10^{5}-10^{6}$ cells/well in RPMI-1640 supplemented medium. Following a $24 \mathrm{~h}$ incubation, the cells were maintained in $\mathrm{CO}_{2}$ incubator at $37^{\circ} \mathrm{C}$ for an additional $48 \mathrm{~h}$ with CIS $(5$ and $20 \mu \mathrm{g} / \mathrm{ml})$ and RSVL $(15 \mu \mathrm{g} / \mathrm{ml})$. The medium was then removed and the cells were washed with PBS and harvested with trypsin/EDTA, followed by a further two washes with PBS. The cell cycle analysis was performed according to the previously described method of Pozarowski and Darzynkiewicz (12), using a flow cytometer (FACSCA; BD Biosciences, Franklin Lakes, NJ, USA).

Assessment of CIS cellular uptake. The cells were seeded in 6 well plates, at a density of $10^{5}-10^{6}$ cells/well in RPMI-1640 
Table I. Effects of cisplatin and/or resveratrol on the growth of parent and cisplatin-resistant HCT-116 colorectal cancer cells.

$$
\mathrm{IC}_{50}(\mu \mathrm{g} / \mathrm{ml})
$$

Treatment

Parent HCT-116 cells

Resistant HCT-116 cells

$\begin{array}{lll}\text { CIS } & 7.9 \pm 0.66 & 20.7 \pm 3.8^{\mathrm{b}} \\ \text { CIS and RSVL }(15 \mu \mathrm{g} / \mathrm{ml}) & 4.2 \pm 0.14^{\mathrm{a}} & 6.15 \pm 0.63^{\mathrm{a}}\end{array}$

The data are expressed as the means \pm standard error of the mean of two experiments, each in duplicate. $\mathrm{IC}_{50}$, the concentration of CIS necessary to produce $50 \%$ inhibition in the growth of cells. ${ }^{\mathrm{a}} \mathrm{P}<0.01$, as compared with the corresponding CIS treatment alone; ${ }^{\text {b }} \mathrm{P}<0.05$, as compared with the parent cells. CIS, cisplatin; RSVL, resveratrol.

Table II. Cisplatin uptake by parent and resistant HCT-116 colorectal cancer cells in the presence of resveratrol.

\begin{tabular}{|c|c|c|c|c|}
\hline \multirow[b]{3}{*}{ Concentration $(\mu \mathrm{g} / \mathrm{ml})$} & \multicolumn{4}{|c|}{ CIS concentration ( $\mathrm{ng} / 10^{6}$ cells) } \\
\hline & \multicolumn{2}{|c|}{ Parent HCT-116 cells } & \multicolumn{2}{|c|}{ Resistant HCT-116 cells } \\
\hline & CIS & CIS+RSVL $(15 \mu \mathrm{g} / \mathrm{ml})$ & CIS & CIS+RSV $(15 \mu \mathrm{g} / \mathrm{ml})$ \\
\hline 5 & $4.36 \pm 0.78$ & $16.2 \pm 1.93^{\mathrm{a}}$ & $1.57 \pm 0.08$ & $4.33 \pm 0.6$ \\
\hline 20 & $72.7 \pm 7.5$ & $110.8 \pm 13.9^{\mathrm{b}}$ & $14.3 \pm 10.11$ & $73.6 \pm 6.1^{b}$ \\
\hline
\end{tabular}

The growing HCT-116 colorectal cancer cells were treated with cisplatin (CIS) and/or resveratrol (RSVL) (15 $\mu \mathrm{g} / \mathrm{ml})$ in combination for $48 \mathrm{~h}$. The cells were then washed once with phosphate-buffered saline and harvested, counted and digested using $1 \%$ nitric acid. Cellular uptake of CIS was determined by inductively coupled plasma mass spectrophotometry. The data are expressed as the means \pm standard error of the mean, of each experiment $(\mathrm{n}=3)$. ${ }^{\mathrm{a}} \mathrm{P}<0.05,{ }^{\mathrm{b}} \mathrm{P}<0.01$, as compared with the corresponding CIS treatment alone.

supplemented medium. The cells were cultured in a $\mathrm{CO}_{2}$ incubator at $37^{\circ} \mathrm{C}$ for $\geq 24 \mathrm{~h}$ prior to treatment, then the cells were incubated with CIS (5 and $20 \mu \mathrm{g} / \mathrm{ml}$ ) either alone or with RSVL $(15 \mu \mathrm{g} / \mathrm{ml})$, for $48 \mathrm{~h}$. Following the treatment, the medium was removed and the cells were washed with PBS, then harvested with trypsin/EDTA. The cells were washed with PBS again and counted, prior to being resuspended $\left(1 \times 10^{6}\right.$ cells/well) in $1 \% \mathrm{HNO}_{3}$ for $24 \mathrm{~h}$ at $70^{\circ} \mathrm{C}$. The lysed cells were analyzed by inductively coupled plasma mass spectrometry (ICP-MS). ICP-MS provides a quantitative analysis of the concentration of an element in aqueous solution, and has a sensitivity of 5 ppt.

Statistical analyses. Statistical analyses were performed using SPSS version 16 (SPSS Inc., Chicago, IL, USA). A one way analysis of variance, followed by a least significant difference post hoc analysis, was used for multiple comparisons. A $\mathrm{P}<0.05$ was considered to indicate a statistically significant difference.

\section{Results}

Effects of RSVL treatment on the cytotoxic activity of CIS. The cytotoxicity of CIS in the parent and CIS-resistant HCT-116 cells was expressed as the surviving fraction following treatment, as compared with the untreated control (Table I and Fig. 1). The parent CRC cells treated with various concentrations of CIS, had an $\mathrm{IC}_{50}$ value of $7.9 \mu \mathrm{g} / \mathrm{ml}$, as compared with the CIS-resistant cells which had an $\mathrm{IC}_{50}$ value of $20.7 \mu \mathrm{g} / \mathrm{ml}$.

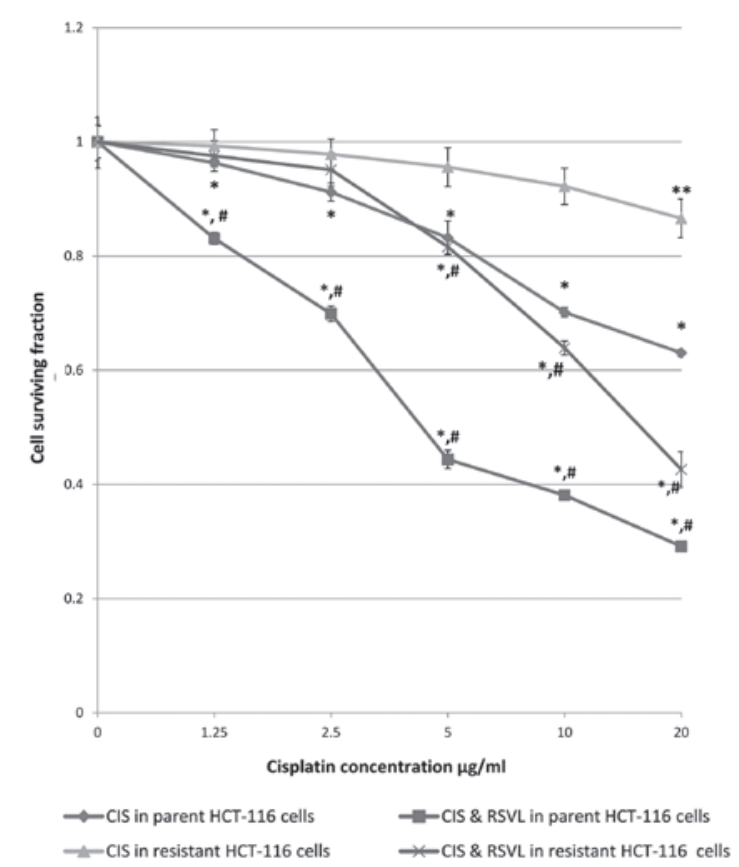

Figure 1. Effects of cisplatin (CIS) and/or resveratrol (RSVL) treatment on the growth of HCT-116 human colorectal cancer cells.

Simultaneous treatment with RSVL $(15 \mu \mathrm{g} / \mathrm{ml})$ resulted in $\mathrm{IC}_{50}$ values of 4.2 and $6.15 \mu \mathrm{g} / \mathrm{ml}$ in the parent and CIS-resistant cells, respectively. 
A

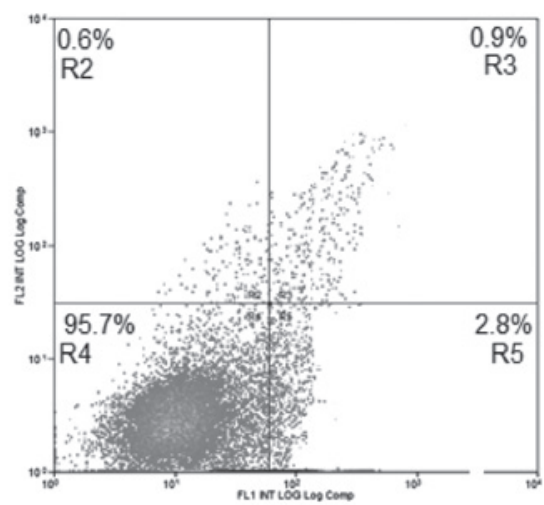

C

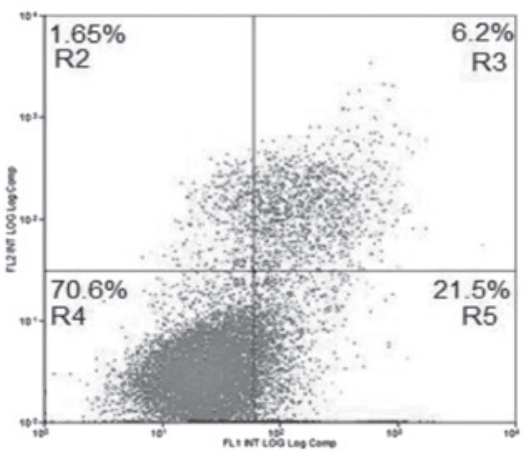

$\mathbf{E}$

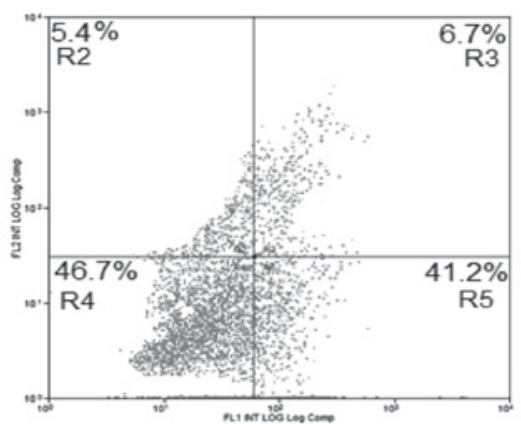

B

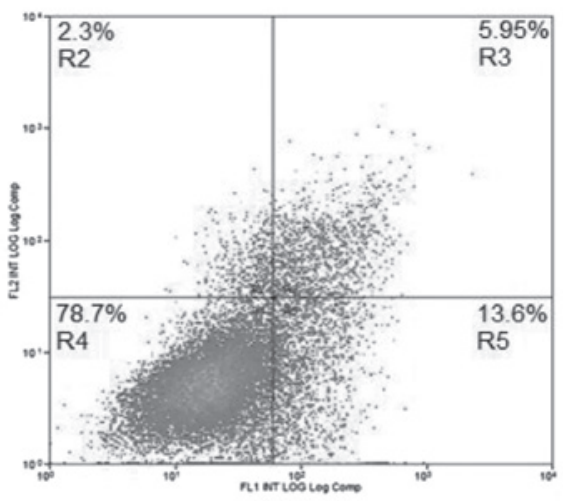

D

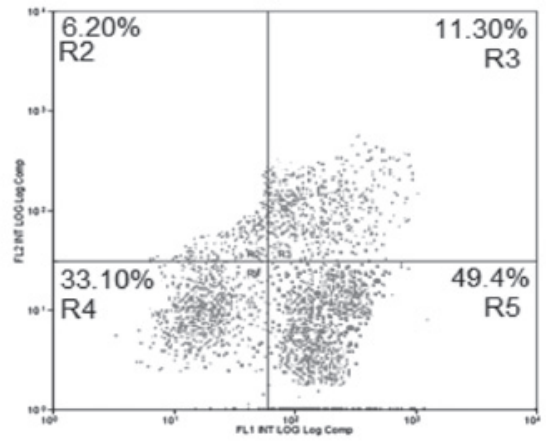

$\mathbf{F}$

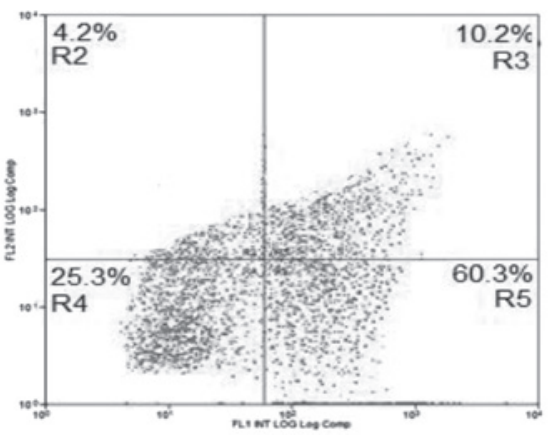

Figure 2. Effects of cisplatin (CIS) and /or resveratrol (RSVL) on the induction of apoptosis in CIS-sensitive HCT-116 colorectal cancer cell. Apoptosis was analyzed following cell exposure to the drugs for $48 \mathrm{~h}$ by staining with Annexin-fluorescein isothiocyanate (FITC) and propodium iodide (PI). (A) Control. (B Cells treated with $15 \mu \mathrm{g} / \mathrm{ml} \mathrm{RSVL}$. (C) Cells treated with $5 \mu \mathrm{g} / \mathrm{ml}$ CIS. (D) Cells treated with $5 \mu \mathrm{g} / \mathrm{ml} \mathrm{CIS} \mathrm{and} 15 \mu \mathrm{g} / \mathrm{ml} \mathrm{RSVL}$. (E) Cells treated with $20 \mu \mathrm{g} / \mathrm{ml} \mathrm{CIS.} \mathrm{(F)} \mathrm{Cells} \mathrm{treated} \mathrm{with} 20 \mu \mathrm{g} / \mathrm{ml} \mathrm{CIS}$ and $15 \mu \mathrm{g} / \mathrm{ml}$ RSVL. The cell percentage in each quadrant are indicated. R2, necrosis; R3, late apoptosis; $\mathrm{R} 4$, viable cell; R5, early apoptosis.

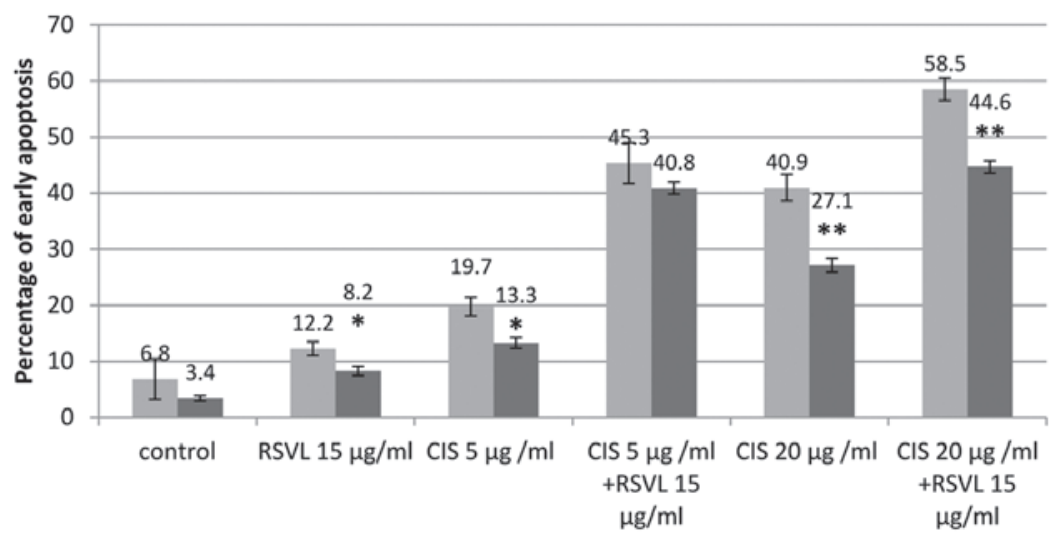

a Parent HCT-116 cells a Resistant HCT-116 cells

Figure 3. Comparison of the percentage of cells in early apoptosis in parent and CIS-resistant HCT-116 colorectal cancer cells. Apoptosis was analyzed following cell exposure to the drugs for $48 \mathrm{~h}$ by staining with annexin-fluorescein isothiocyanate and propidium iodide. The data are expressed as the means \pm standard error of the mean of two experiments, each in duplicate. ${ }^{*} \mathrm{P}<0.05,{ }^{* *} \mathrm{P}<0.01$, as compared with the parent cells. 
A1

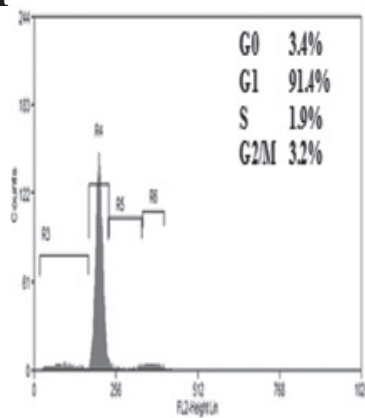

C1

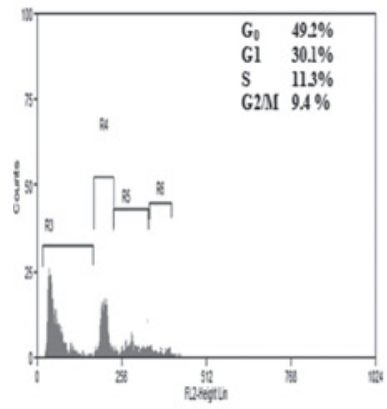

E1

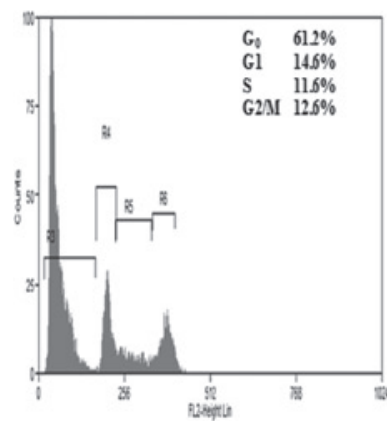

A2

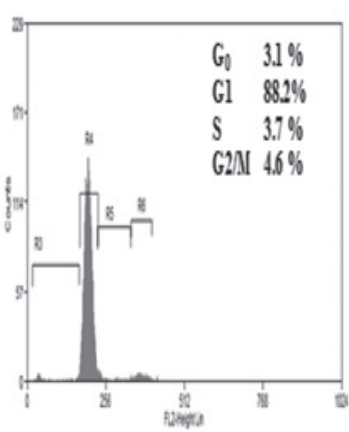

C2

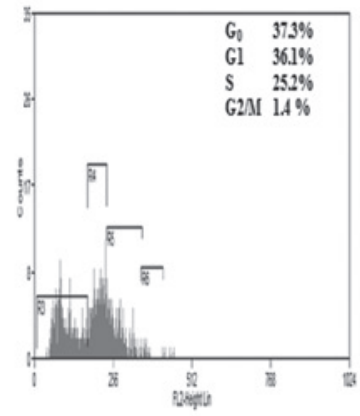

E2

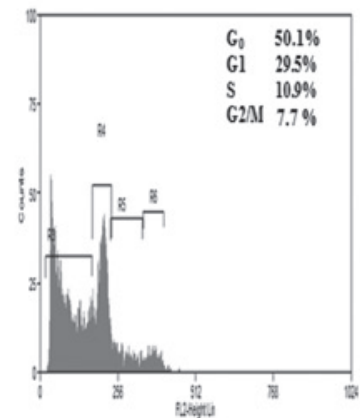

B1

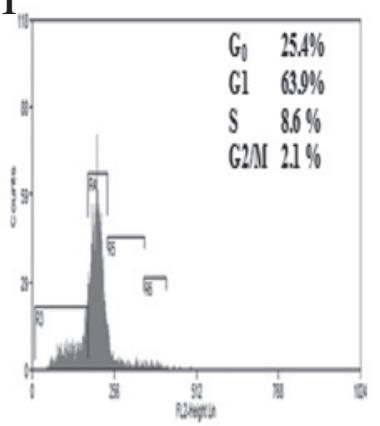

D1

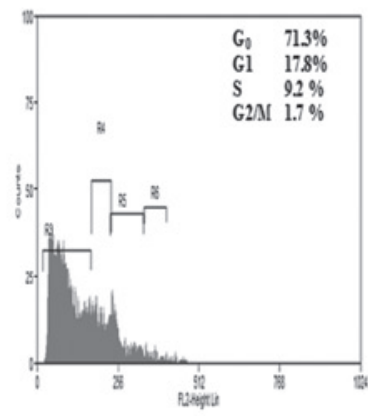

F1

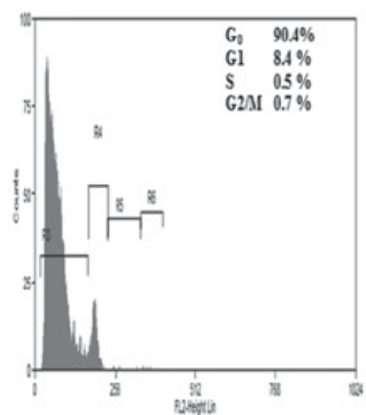

B2

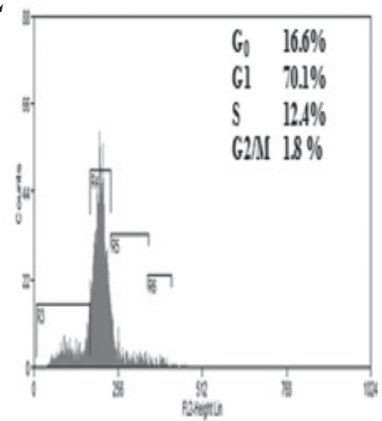

D2

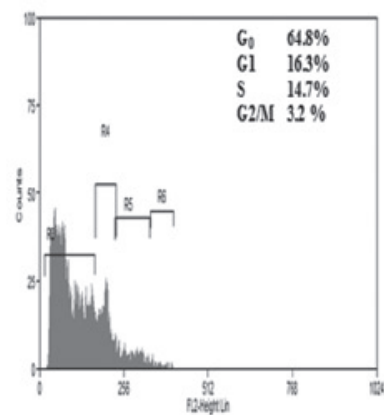

F2

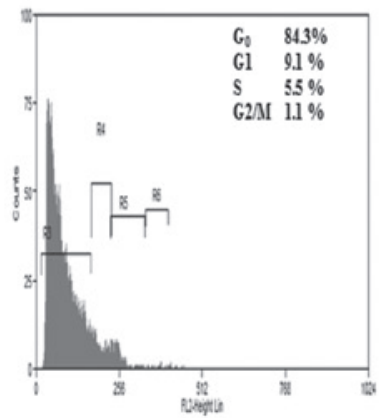

Figure 4. Effects of cisplatin (CIS) and/or resveratrol (RSVL) on cell cycle phase distribution of the parent and CIS-resistant HCT-116 colorectal cancer cells. The cell cycle distribution was analyzed following cell exposure to CIS and RSVL for $48 \mathrm{~h}$ by staining with propidium iodide. (A) Control. (B) Cells treated with $15 \mu \mathrm{g} / \mathrm{ml}$ RSVL. (C) Cells treated with $5 \mu \mathrm{g} / \mathrm{ml}$ CIS. (D) Cells treated with $5 \mu \mathrm{g} / \mathrm{ml} \mathrm{CIS} \mathrm{and} 15 \mu \mathrm{g} / \mathrm{ml} \mathrm{RSVL}$. (E) Cells treated with $20 \mu \mathrm{g} / \mathrm{ml}$ CIS. (F) Cells treated with $20 \mu \mathrm{g} / \mathrm{ml} \mathrm{CIS}$ and $15 \mu \mathrm{g} / \mathrm{ml}$ RSVL. A1-F1, parent HCT-116 cells; A2-F2, resistant HCT-116 cells.

Percentage of cells in Go phase in sensitive against resistance cells

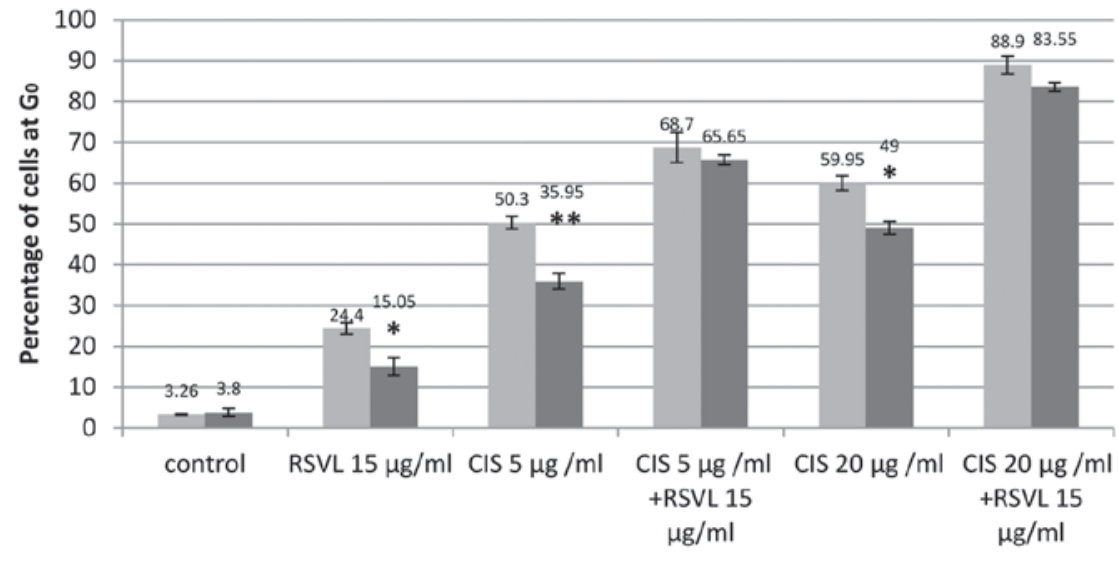

a Parent HCT-116 cells = Resistant HCT-116 cells

Figure 5. Effects of cisplatin (CIS) and/or resveratrol (RSVL) on cell cycle phase distribution between parent and resistant HCT-116 colorectal cancer cells. Cell cycle distribution was analyzed following cell exposure to the drugs for $48 \mathrm{~h}$, by staining with propidium iodide. The data are expressed as the means \pm standard error of the mean of two experiments, each in duplicate. ${ }^{*} \mathrm{P}<0.05,{ }^{* *} \mathrm{P}<0.01$, as compared with the parent cells. 
Effects of RSVL and CIS treatment on the induction of apoptosis. The HCT-116 cells were stained with Annexin V-FITC and PI and the rate of apoptosis was analyzed using flow cytometry. The percentage of the parent HCT-116 cells in early apoptosis, when treated with CIS at 5 and $20 \mu \mathrm{g} / \mathrm{ml}$, was 19.7 and $40.9 \%$, respectively. The addition of RSVL $(15 \mu \mathrm{g} / \mathrm{ml})$, in combination with the same doses of CIS, resulted in a significant increase in the percentage of cells in early apoptosis (45.3 and 58.8\%, respectively; Fig. 2 and 3 ).

Effects of RSVL and CIS treatment on the cell cycle phase progression of HCT-116 cells. The treatment of the cells with RSVL $(15 \mu \mathrm{g} / \mathrm{ml})$ resulted in a preferential accumulation of the cells in $G_{0}$ and $S$ phases, at the expense of $G_{1}$ phase cells (Fig. 4). The percentage of accumulation was 24.4 and $8.6 \%$ in the $\mathrm{G}_{0}$ and $\mathrm{S}$ phases, respectively.

Simultaneous treatment of CIS (5 and $20 \mu \mathrm{g} / \mathrm{ml}$ ) with RSVL $(15 \mu \mathrm{g} / \mathrm{ml})$ resulted in a significant increase in the percentage of cells in the $\mathrm{G}_{0}$ phase of parent cells, to 68.7 and $88.9 \%$ respectively (Fig. 4 and 5).

Effects of RSVL on uptake of CIS in HCT-116 cells. The cellular uptake of $5 \mu \mathrm{g} / \mathrm{ml}$ CIS in parent and CIS-resistant cells was 4.36 and $1.57 \mathrm{ng} / 10^{6}$ cells, respectively. The uptake of CIS was significantly increased in the presence of $15 \mu \mathrm{g} / \mathrm{ml}$ RSVL, to 16.2 and $4.33 \mathrm{ng} / 10^{6}$ cells respectively (Table II).

Similarly, $20 \mu \mathrm{g} / \mathrm{ml}$ CIS treatment resulted in a cellular uptake of 72.7 and $14.3 \mathrm{ng} / 10^{6}$ in the parent and CIS-resistant cells, whereas in the presence of RSVL $(15 \mu \mathrm{g} / \mathrm{ml})$ the uptake of CIS increased to 110.8 and $73.6 \mathrm{ng} / 10^{6}$ cells, respectively.

\section{Discussion}

CIS is one of the most active cytotoxic agents in current use, with a proven efficacy in numerous human malignancies, either alone or in combination with other cytocidal drugs. However, its clinical usefulness has been restricted by detrimental side effects, including nephrotoxicity $(3,4)$. In an attempt to minimize the side effects of cisplatin, and at the same time increase its anticancer efficacy, various approaches have been attempted. One approach is the search for natural compounds with chemopreventive or anticancer properties, that may be used in combination with CIS. A potential natural chemosensitizer is RSVL; therefore, in the present study, the modulatory effects of RSVL on the cytotoxic activity of CIS were determined against the growth of parent and CIS-resistant CRC cells. The treatment of HCT-116 cells with different CIS doses was shown to be cytotoxic to the cells. There was a 2.6 fold increase in the $\mathrm{IC}_{50}$ in the CIS-resistant cells, as compared with the parent cells. It is known that CIS-induced DNA damage occurs through an initial transient $\mathrm{S}$ phase arrest of the cancer cells, followed by inhibition of the Cdc2-cyclin A or B kinases, which results in a persistent $\mathrm{G}_{2} / \mathrm{M}$ phase arrest $(13,14)$. In the present study an induction of early apoptosis was observed in the treated cells, with an accumulation of the cells in $G_{0}$ and $S$ phases. The precise mechanism of action of platinum analogs remains unclear. It is currently known that platinum analogs destroy tumor cells in all stages of the cell cycle and bind DNA through the formation of intra- and inter-strand cross-links, thereby leading to inhibition of DNA synthesis and function (15-17). Tumor cell resistance to CIS and its analogs is still not completely understood, and various mechanisms are likely to be involved, which may be multifactorial and lead to severe limitations in the medical efficacy of CIS $(18,19)$. Decreasing intracellular CIS accumulation has been identified as a major cause of acquired resistance, and may be due to either inhibited drug uptake or increased drug efflux $(19,20)$. The present study showed a 5 fold decrease in the cellular uptake of CIS $(20 \mu \mathrm{g} / \mathrm{ml})$ into the CIS-resistant cells, as compared with the parent cells. This may be due to overexpression of P-glycoprotein (Pgp), which is a representative membrane efflux pump encoded for by the multidrug resistance 1 (MDR1) gene, which may reduce the intracellular levels of drug accumulation (21). In the human intestine, Pgp has been shown to be strongly expressed on the apical surface of the superficial columnar epithelial cells of the ileum and colon, and its expression levels were shown to reduce in a gradual manner in the jejunum, duodenum and stomach (22-24).

In the present study, RSVL was tested as a candidate for sensitizing CRC cells to the action of CIS, in both CIS-resistant and parent cells. RSVL treatment increased the cytotoxic activity of CIS against the growth of both parent and CIS-resistant cells, with an $\mathrm{IC}_{50} 3.2$ fold less in the CIS-resistant cells, as compared to 1.8 fold in the parent cells (Fig. 1 and Table I). This result was accompanied by an increase in the percentage of apoptotic cells, an increased accumulation of cells in $G_{0}$ phase and an increased cellular uptake of CIS in the CIS-resistant and parent cells. There was a 5.1 fold increase in the uptake of CIS in the CIS-resistant cells in response to RSVL treatment, as compared with the parent cells. These results imply that RSVL not only exposed higher proportions of CRC cells to CIS, by inducing cell cycle arrest in the $G_{0}$ and $S$ phases, but also increased the concentration of CIS available inside the parent and CIS-resistant cells, with an increased accumulation in the CIS-resistant cells. The increase in the cellular uptake of CIS in the HCT-116 cells may be due to the inhibition of Pgp (25), which has an important role in the absorption, distribution and elimination of CIS; therefore, determining its efficiency and toxicity (26). Conversely, Wang et al (27), demonstrated that RSVL enhanced the activity of Pgp. These conflicting findings may be explained on the basis that multi-drug resistance may be acquired following an initial exposure to anticancer drugs (28). In addition, previous studies have shown that some Pgp antagonists, such as verapamil and cyclosporine A, may induce Pgp expression in colon carcinoma cells (29). However, the time needed for expression and inhibition of Pgp by their antagonists remains controversial. One way to enhance the cytotoxicity of CIS in sensitive and resistant CRC cells may be to target the FOXO3a signaling pathway (30). Further findings from the authors of the present study showed that induction of FOXOa expression in the presence of RSVL in HTC-116 cells (data not shown).

In conclusion, RSVL treatment increased the cytotoxic activity of CIS against the growth of CRC cells, with pronounced effects in CIS-resistant cells, through alteration of the cell cycle and an increased cellular uptake of CIS. 


\section{Acknowledgements}

This study was funded by the Deanship of scientific research (DSR). King Abdulaziz University, Jeddah (grant no. $1433 / 140 / 110)$. The authors, therefore, would like to thank the DSR for financial support.

\section{References}

1. Ibrahim EM, Zeeneldin AA, El-Khodary TR, Al-Gahmi AM and Bin Sadiq BM: Past, present and future of colorectal cancer in the Kingdom of Saudi Arabia. Saudi J Gastroenterol 14 178-182, 2008.

2. Al-Ahwal MS, Shafik YH and Al-Ahwal HM: First national survival data for colorectal cancer among Saudis between 1994 and 2004: what's next? BMC Public Health 13: 73, 2013.

3. Aggarwal BB, Bhardwaj A, Aggarwal RS, Seeram NP Shishodia $S$ and Takada Y: Role of resveratrol in prevention and therapy of cancer: preclinical and clinical studies. Anticancer Res 24: 2783-2840, 2004.

4. Taguchi T, Nazneen A, Abid MR and Razzaque MS: Cisplatin-associated nephrotoxicity and pathological events Contrib Nephol 148: 107-121, 2005.

5. al-Harbi MM, Osman AM, al-Gharably AM, et al: Effect of desferrioxamine on cisplatin-induced nephotoxicity in normal rats. Chemotherapy 41: 448-454, 1995.

6. Osman AM, Al-sedairy ST and Moran IM: Verapamil enhancement of antitumour effect of cisdiamminodichloroplatin (II) in mouse bearing ehlich ascites carcinoma cells. Med Sci Res 24: 429-431, 1996.

7. Osman AM, Mohamed MA, Abdel-Wahab AA, and Ahmed MS Modulation by verapamil of doxorubicin induced expression of multidrug resistance gene (mdr-1/P-glycoprotein) in murine tumour cells. J Egypt Nat Cancer Inst 12: 221-227, 2000.

8. Arafa HM, Abdel-Hamid MA, El-Khouly AA, Elmazar MM, and Osman AM: Enhancement by dexamethasone of the therapeutic benefits of cisplatin via regulation of tumor angiogenesis and cell cycle kinetics in a murine tumor paradigm. Toxicology 222: 103-113, 2006

9. Baur JA and Sinclair DA: Therapeutic potential of resveratrol: the in vivo evidence. Nat Rev Drug Discov 5: 493-506, 2006.

10. Skehan P, Storeng R, Scudiero D, et al: New colorimetric cytotoxicity assay for anticancer-drug screening. J Natl Cancer Inst $82: 1107-1112,1990$.

11. Kuypers FA, Lewis RA, Hua M, Schott MA, Discher D, Ernst JD and Lubin BH: Detection of altered membrane phospholipid asymmetry in subpopulations of human red blood cells using fluorescently labeled annexin V. Blood 187: 1179-87, 1996.

12. Pozarowski P and Darzynkiewicz Z: Analysis of cell cycle by flow cytometry. Methods Mol Biol 281: 301-311, 2004

13. Shi L, Nishioka WK, Th'ng J, Bradbury EM, Litchfield DW and Greenberg AH: Premature p34cdc2 activation required for apoptosis. Science 263: 1143-1145, 1994.
14. Shapiro GI and Harper JW: Anticancer drug targets: cell cycle and checkpoint control. J Clin Invest 104: 1645-1653, 1999.

15. Wang D and Lippard SJ: Cellular processing of platinum anticancer drugs. Nat Rev Drug Discov 4: 307-320, 2005.

16. Ciccarelli RB, Solomon MJ, Varshavsky A and Lippard SJ: In vivo effects of cis- and trans-diamminedichloroplatinum(II) on SV40 chomosomes: differential repair, DNA-protein cross-linking, and inhibition of replication. Biochemistry 24: 7533-7540, 1985.

17. Eastman A: The formation, isolation and characterization of DNA adducts produced by anticancer platinum complexes. Pharmacol Ther 34: 155-166, 1987.

18. Brabec $\mathrm{V}$ and Kasparkova $\mathrm{J}$ : Modifications of DNA by platinum complexes. Relation to resistance of tumors to platinum antitumor drugs. Drug Resist Updat 8: 131-146, 2005.

19. Florea AM and Büsselberg D: Cisplatin as an anti-tumor drug: cellular mechanisms of activity, drug resistance and induced side effects. Cancers (Basel) 3: 1351-1371, 2011.

20. Kartalou M. and Essigmann JM: Mechanisms of resistance to cisplatin. Mutat Res 478, 23-43, 2001.

21. Ho GT, Moodie FM and Satsangi J: Multidrug resistance 1 gene (P-glycoprotein 170): an important determinant in gastrointestinal disease? Gut 52: 759-766, 2003.

22. Gupta SC, Kannappan R, Reuter S, Kim JH and Aggarwal BB Chemosensitization of tumors by resveratrol. Ann NY Acad Sci 1215: 150-160, 2011.

23. Kool M, de Haas M, Scheffer GL, et al: Analysis of expression of cMOAT (MRP2), MRP3, MRP4, and MRP5, homologues of the multidrug resistance-associated protein gene (MRP1), in human cancer cell lines. Cancer Res 57: 3537-3547, 1997.

24. Tanida S, Mizoshita T, Ozeki K, et al: Mechanisms of cisplatin-induced apoptosis and of cisplatin sensitivity: potential of BIN1 to act as a potent predictor of cisplatin sensitivity in gastric cancer treatment. Int J Surg Oncol 2012: $862879,2012$.

25. Al-Abd AM, Mahmoud AM,El-Sherbiny GA, et al: Resveratrol enhances the cytotoxic profile of docetaxel and doxorubicin in solid tumour cell lines in vitro. Cell Prolif 44: 591-601, 2011.

26. Rezk YA, Balulad SS, Keller RS and Bennett JA: Use of resveratrol to improve the effectiveness of cisplatin and doxorubicin: study in human gynecologic cancer cell lines and in rodent heart. Am J Obstet Gynecol 194: e23-e26, 2006.

27. Wang Y, Romigh T, He X, et al: Resveratrol regulates the PTEN/AKT pathway though androgen receptor-dependent and -independent mechanisms in prostate cancer cell lines. Hum Mol Genet 19: 4319-4329, 2010.

28. Chaudhary PM and Roninson IB: Induction of multidrug resistance in human cells by transient exposure to different chemotherapeutic drugs. J Natl Cancer Inst 85: 632-639, 1993.

29. Herzog C, Tsokos M, Bates SE and Fojo AT: Increased mdr-1/P-glycoprotein expression after treatment of human colon carcinoma cells with P-glycoprotein antagonists. J Biol Chem 268: 2946-2952, 1993.

30. Fernández de Mattos S, Villalonga P, Clardy J, and Lam EW: FOXO3a mediates the cytotoxic effects of cisplatin in colon cancer cells. Mol Cancer Ther 7: 3237-3246, 2008. 